\title{
Factors Affecting the Use of Print and Electronic Books: A Use Study and Discussion
}

\author{
Amy Fry
}

\begin{abstract}
This article outlines a study assessing and comparing the rate of use of nonreference print and electronic book collections acquired during the same time period at one academic library. Rate of use was examined for both collections by discipline and method of acquisition. The author found that 74 percent of print titles acquired in 2008-2009 had been used within their first six years in the collection, and that 27 percent of print books acquired between 2008 and 2014 had been used between July 2013 and November 2014. By contrast, only 12 percent of the e-books acquired between 2008 and 2014 were used during the same 17-month period. The author examines how different print and electronic collection development models might affect monograph use in academic libraries within the context of previously published research.
\end{abstract}

\section{Introduction}

This article outlines a study assessing and comparing the rate of use of nonreference print and electronic book collections by discipline and method of acquisition acquired during the same time period at one academic library. The author uses this data to explore, within the context of previously published research, how different collection development methods (firm-order and approval plans for print books and demanddriven acquisition of e-books) impact monograph use in academic libraries, whether print books have lost their value for library users, and how libraries can assess if and/ or when e-books are used more than print. This study is unique in attempting to compare use of all of a library's nonreference print and electronic monographs acquired during the same time period and also in its discussion of the rate of use of e-books from multiple studies. Thus, the article offers new perspectives on the transition of academic library collections from print to electronic format.

\section{Literature Review}

Use of print collections in academic libraries has been a rich area of research in library science for decades. Usage studies span collections from small special libraries to large research libraries and consortia. Though each study is different, most measure what 
percentage of a part of the library's collection (usually defined either by publication date or acquisition date) received use (measured either by circulations only or circulations combined with in-house use counts) during a given time period.

The frequently cited Pittsburgh study examined collection use at the University of Pittsburgh between 1969 and $1975 .{ }^{1}$ It revealed that only 60 percent of books purchased there in 1969 had circulated at least once in their first seven years in the collection. This figure is frequently cited as the benchmark for use that most academic libraries' print collections experience, though an exploration of the published literature shows that, in fact, rate of collection use as demonstrated in published studies varies widely (as great as 91 percent and as low as 34 percent).

\begin{tabular}{|l|l|l|l|}
\hline \multicolumn{4}{|c|}{ TABLE 1 } \\
\hline \multicolumn{4}{|c|}{ Published Print Use Studies, 1942-2012 } \\
\hline Institution & $\begin{array}{l}\text { 1\% } \\
\text { Use }\end{array}$ & $\begin{array}{l}\text { Time } \\
\text { Owned }\end{array}$ & $\begin{array}{l}\text { Study } \\
\text { Date }\end{array}$ \\
\hline a. Louisiana State University & $45 \%$ & 1 year & 1992 \\
\hline b. Muhlenberg College & $45 \%$ & 1 year & 1942 \\
\hline c. Western Michigan & $54 \%$ & 1.3 years & 1995 \\
\hline d. Pennsylvania State University & $69 \%$ & $1-3$ years & 2007 \\
\hline e. University of Illinois at Urbana-Champaign & $60 \%$ & $1-3$ years & 2007 \\
\hline f. Kent State & $62 \%$ & $1-3.5$ years & 2012 \\
\hline g. CARLI Libraries (Illinois Academic Libraries) & $66 \%$ & $1-5$ years & 2008 \\
\hline h. University of Illinois at Chicago Health Sciences Library & $58 \%$ & 2 months- & 1989 \\
& & 2 years & \\
\hline i. University of Illinois at Chicago Health Sciences Library & $81 \%$ & 3 years & 1995 \\
\hline j. University of Denver & $58 \%$ & 4 years & 2009 \\
\hline k. University of New Mexico Health Sciences Center Library & $91 \%$ & 4 years & 1993 \\
\hline 1. Asbury Theological Seminary Libraries & $34 \%$ & $4-9$ years & 2012 \\
\hline m. Lingnan University, Hong Kong & $67 \%$ & 6 years & 2010 \\
\hline n. Cornell University & $45 \%$ & $0-20$ years & 2010 \\
\hline
\end{tabular}

Moreover, variations in the literature on print use make it very difficult to generalize the conclusions of any one study to all libraries. This is not only because collection use is influenced by a variety of factors that will differ from library to library, but also because the studies themselves are all a little different. Some include in-house use; others do not. Some only include approval books; others do not. The amount of time the books have been available in the collection also varies from study to study.

There are no follow-up studies to show how many of the unused books in one study ultimately do get used. It's impossible to extrapolate from the data that exist to come up with a "typical" value for the use of print collections.

Rate of use has also been employed to assess publisher and aggregator e-book collections. Like print use studies, these studies show rates of use that vary widely.

In 2001, Langston found that 94 percent of 1,522 e-books available to all 23 California State University libraries received at least one use between May and December $2001 .^{3}$ Bucknell looked at the number of Springer e-books used at the University of Liverpool in 2009 and found that 48 percent of 2005-2008 imprints and 40 percent of 2009 imprints were used at least once that year. ${ }^{4}$ At Seton Hall, Rose-Wiles found that 55 percent of 
214 individually purchased e-brary e-books added between 2009 and 2011 were used in 2011, but only 7.2 percent of "a large business collection" of e-books was used in 2009 , the first year it was available. ${ }^{5}$

Knowlton looked at the percent of titles used in a collection of e-books and compared it to the percent of titles used in a collection of print books to determine the percent expected use (PEU) of e-books in different subject areas at the University of Memphis. ${ }^{6}$ His methodology closely mirrored the methodology employed in the current study, with a few differences. Knowlton compared the rate of use of a group of e-books to the rate of use of a group of print books during an identical time period (academic year 2013-2014), but he chose groups of titles based on publication date rather than acquisition date (resulting in groups more equivalent in size than in the current study), and limited his examination of e-books to one aggregator collection: those available via e-books on EBSCOhost. Knowlton found that 16.1 percent of the print books received use during the time period studied while only 10.4 percent of the electronic titles received any use.

The majority of quantitative use studies of e-books have looked at the use of e-books acquired via DDA (demand-driven acquisition). In this method of acquisition, records for e-books are loaded into the library's catalog, and patron use determines which titles are purchased. Though the authors of these studies usually focus on metrics such as cost and which subjects and publishers receive the highest number of purchases, they also typically include statistics for how many titles were made available to users and how many received use or received enough use to be purchased during the time covered in the study. As the published data reveals, the percentage of e-book titles used or purchased in these programs has ranged from about 4 to 14 percent, despite the fact that the DDA records in these studies were profiled before loading to be relevant, recent, and academic in nature.

\begin{tabular}{|l|l|l|l|l|}
\hline \multicolumn{5}{|c|}{$\begin{array}{c}\text { TABLE 2 } \\
\text { DDA Studies, 2010-2014 }\end{array}$} \\
\hline \multicolumn{1}{|c|}{ Institution } & $\begin{array}{l}\text { Number } \\
\text { of } \\
\text { Records } \\
\text { Available }\end{array}$ & $\begin{array}{l}\text { Time Period } \\
\text { Titles Available }\end{array}$ & $\%$ Use & \multicolumn{1}{|c|}{ Scope of Records } \\
\hline $\begin{array}{l}\text { a. University } \\
\text { of Illinois } \\
\text { at Urbana- } \\
\text { Champaign }\end{array}$ & 6,000 & $\begin{array}{l}4 \text { months } \\
\text { (April-July } \\
2010)\end{array}$ & $11 \%$ & $\begin{array}{l}\text { Not owned, under \$200, in } \\
\text { English, academic, recently } \\
\text { published, some subjects } \\
\text { excluded }\end{array}$ \\
\hline $\begin{array}{l}\text { b. University } \\
\text { of Illinois } \\
\text { at Urbana- } \\
\text { Champaign }\end{array}$ & 8,792 & $\begin{array}{l}6 \text { months } \\
\text { (November } \\
2012-\text { April } \\
2013)\end{array}$ & $4 \%$ & $\begin{array}{l}\text { Six humanities disciplines, } \\
\text { academic, recently } \\
\text { published, no literature/ } \\
\text { serials/reference, focus on } \\
\text { university presses }\end{array}$ \\
\hline $\begin{array}{l}\text { c. University } \\
\text { College Dublin }\end{array}$ & 19,337 & $\begin{array}{l}6 \text { months (May- } \\
\text { October 2013) }\end{array}$ & $\begin{array}{l}5.8 \% \\
(\text { purchased) }\end{array}$ & $\begin{array}{l}\text { Detailed subject profiles, } \\
\text { recently published }\end{array}$ \\
\hline $\begin{array}{l}\text { d. Colorado } \\
\text { State } \\
\text { University }\end{array}$ & 7,942 & $\begin{array}{l}8 \text { months (May- } \\
\text { December 2010) }\end{array}$ & $11.9 \%$ & $\begin{array}{l}\text { Select providers, recently } \\
\text { published, English, under } \\
\text { \$300, certain subjects } \\
\text { excluded }\end{array}$ \\
\hline
\end{tabular}




\begin{tabular}{|c|c|c|c|c|}
\hline \multicolumn{5}{|c|}{$\begin{array}{c}\text { TABLE } 2 \\
\text { DDA Studies, 2010-2014 }\end{array}$} \\
\hline Institution & $\begin{array}{l}\begin{array}{c}\text { Number } \\
\text { of } \\
\text { Records }\end{array} \\
\text { Available }\end{array}$ & $\begin{array}{c}\text { Time Period } \\
\text { Titles Available }\end{array}$ & $\%$ Use & Scope of Records \\
\hline $\begin{array}{l}\text { e. University } \\
\text { of Iowa }\end{array}$ & 12,947 & $\begin{array}{l}11 \text { months } \\
\text { (September } \\
\text { 2009-July } \\
2010 \text { ) }\end{array}$ & $\begin{array}{l}6.6 \% \\
\text { (purchased) }\end{array}$ & $\begin{array}{l}\text { Recently published, under } \\
\$ 250 \text {, not currently } \\
\text { available electronically, } \\
\text { excluding popular titles } \\
\text { and K's, following print } \\
\text { approval profile but with } \\
\text { fewer exclusions }\end{array}$ \\
\hline $\begin{array}{l}\text { f. Kent State } \\
\text { University }\end{array}$ & 22,018 & $\begin{array}{l}1 \text { year (January- } \\
\text { December } \\
\text { 2012) }\end{array}$ & $8.2 \%$ & $\begin{array}{l}\text { Recently published, } \\
\text { following subjects from } \\
\text { print approval profile }\end{array}$ \\
\hline $\begin{array}{l}\text { g. University } \\
\text { of Arkansas }\end{array}$ & 19,194 & $\begin{array}{l}14 \text { months } \\
\text { (June 2012- } \\
\text { September } \\
\text { 2013) }\end{array}$ & $6 \%$ & $\begin{array}{l}\text { Academic, no textbooks, } \\
\text { under } \$ 250 \text {, mirroring } \\
\text { approval plan }\end{array}$ \\
\hline $\begin{array}{l}\text { h. Hong Kong } \\
\text { University of } \\
\text { Science and } \\
\text { Technology }\end{array}$ & 22,117 & $\begin{array}{l}1 \text { year } 9 \text { months } \\
\text { (October 2012- } \\
\text { June 2014) }\end{array}$ & $13.9 \%$ & $\begin{array}{l}\text { Under } \$ 250 \text {, recently } \\
\text { published, following } \\
\text { subject and nonsubject } \\
\text { parameters of slip profile }\end{array}$ \\
\hline $\begin{array}{l}\text { i. University of } \\
\text { Arizona }\end{array}$ & 594,000 & $\begin{array}{l}2.5 \text { years (July } \\
\text { 2011-December } \\
2013)\end{array}$ & $\begin{array}{l}10 \% \\
\text { (purchased) }\end{array}$ & $\begin{array}{l}\text { Recently published, } \\
\text { academic, no textbooks, } \\
\text { popular fiction or manuals }\end{array}$ \\
\hline
\end{tabular}

When compared to the results of print use studies, it is evident that existing quantitative studies of e-book use from DDA plans demonstrate a much lower rate of use (as measured by quantity of titles available receiving any use) than existing quantitative studies of print books. One reason for the low rate of overall use in DDA studies may be because the titles studied were only available for a short time before their percent use was recorded, often less than one year, while the titles in print studies were usually available for much longer. However, it is important to note that DDA programs appear to result in the use of a narrower range of available titles than those in more traditionally acquired print collections.

A number of studies have attempted to compare e-book and print book use, usually (though not always) by comparing vendor-supplied use counts of e-books (in the form of accesses or downloads) to circulations of those same titles held in print. This is problematic, because one e-book "access" will involve a user doing one of many actions, such as looking at the table of contents, downloading a chapter, doing a search, or reading any number of pages. One circulation of a print book can represent hundreds of such actions - or none. Though both statistics are valuable information for assessment, these measurements are simply not comparable.

Some researchers have used these kinds of data to claim that e-books are used more than print, but looking at percent titles used shows that this is only sometimes the case. ${ }^{8}$ Littman and Connaway compared the use of 7,880 titles at Duke University and found that 40 percent of the books were used electronically between February 2001 and August 
2002, while 35.5 percent were used in print. ${ }^{9}$ In Christian and Aucoin's study of the use of 2,852 books at Louisiana State University in 2002, not only did more of the print books receive use ( $29.27 \%$ vs. $19.6 \%$ of the electronic books), their total circulations were higher than the total number of e-book accesses. ${ }^{10}$ Kimball, Ives, and Jackson showed that, of 4,288 science and technology titles available at Texas A\&M, 14 percent and 13 percent of e-books and print books, respectively, received use between June 2006 and July 2007. ${ }^{11}$ Downey et al. compared the circulation of 20,030 print books at Kent State University to the use of 22,018 e-books made available via DDA records: 62.5 percent of the print books circulated at least once in calendar year 2012, while only 8.2 percent of the e-books received at least one use that year. (An important factor in the difference between these two figures is the fact that the print books had been in the collection for between 1 and 2.5 years, while the e-books had only been available for between six months and one year. $)^{12}$ In contrast to the aforementioned studies, Goodwin compared the use of 275 titles at Coastal Carolina University between April 2011 and October 2013 and found that 75.6 percent of the titles were used electronically, while only 29.1 percent were used in print. $^{13}$

\section{Methodology}

Two methods were used at Bowling Green State University (BGSU) to assess the use of recently acquired nonreference print books. The first involved evaluating what percent of titles acquired between July 2008 and June 2014 had received at least one circulation or recorded in-house use since their acquisition. The second involved determining what percent of the same group of titles had received at least one use (specifically a circulation) between July 2013 and November 2014. This was the period represented by the "last year/year-to-date" fields for circulation counts in BGSU's integrated library system (Innovative's Sierra) at the time the data were collected. In-house use from July 2013 to November 2014 could not be calculated, because there is no mechanism for recording in-house use by date in Sierra.

In November 2014, the author used the "create lists" function in Sierra to export lists of all items acquired during each of the six fiscal years 2008-2009 through 2013-2014 and shelved, as of November 2014, in the main circulating collection. Titles with multiple item records attached to the bibliographic records were removed to simplify the analysis process (these titles equaled $1 \%-3 \%$ of the titles in each list). Next, titles with purchase fund codes that indicated they were not firm order or approval purchases were also removed.

The titles in the study were divided into six disciplines and 42 subjects based on call number ranges (see table 3). The call numbers were normalized using Conley and Nolan's formula for Excel. ${ }^{14}$

Percent use was calculated for the titles purchased in each year from 2008-2009 through 2012-2013 by determining how many titles purchased in each year had at least one recorded circulation or in-house use in Sierra from the date of order through November 2014.

The library's nonreference e-books were similarly assessed. While it would have been ideal to determine the number of zero-use titles in all of BGSU's e-book packages acquired between 2008 and 2014, the data to do this was simply not available. Therefore, the author examined what percent of nonreference e-books acquired between 2008 and 2014 received at least one use (as defined by a download) between July 2013 and November 2014. This is the same time period represented in the "last year/year-to-date" circulation count for the lists of print books included in the study. Five e-book packages containing 73,148 titles were examined; these fit the criteria of being: a) mainly nonreference monographs; b) acquired since 2008; c) books for which title-level usage 


\begin{tabular}{|c|c|c|}
\hline \multicolumn{3}{|c|}{$\begin{array}{c}\text { TABLE } 3 \\
\text { Discipline, Subject, and Library of Congress Classification Breakdown Used }\end{array}$} \\
\hline Discipline & \begin{tabular}{|c|} 
Subjects \\
\end{tabular} & LC Classes \\
\hline Business & Business & HE, HF, HG, HJ \\
\hline Education & Education & $\mathrm{L}$ \\
\hline General & General & A \\
\hline Humanities & $\begin{array}{l}\text { Architecture, film, fine arts, languages \& } \\
\text { linguistics, languages \& literatures (Asian), } \\
\text { languages \& literatures (Romance), literature } \\
\text { (English \& American), literature (general), } \\
\text { literature (Germanic), music, philosophy, } \\
\text { photography, religion }\end{array}$ & $\begin{array}{l}\text { NA; PN1994-PN1999; N, } \\
\text { NB-NX; P-PH, PM; PJ, } \\
\text { PK, PL; PQ; PR, PS, PZ; } \\
\text { PN; PT; M; B, BC, BD, } \\
\text { BH, BJ; TR; BL, BM-BX }\end{array}$ \\
\hline Sciences & $\begin{array}{l}\text { Agriculture, biological sciences \& general } \\
\text { science, chemistry, computer science, } \\
\text { environmental sciences } \\
\text { \& ecology, geography, geology, mathematics, } \\
\text { medicine, military \& naval science, physics \& } \\
\text { astronomy, recreation \& leisure, technology }\end{array}$ & $\begin{array}{l}\text { S; Q, QH-QR; QD; } \\
\text { QA76-QA90; GE, GF; } \\
\text { G-GC; QE; QA (except } \\
\text { QA76-QA90); R; U-V; } \\
\text { QB, QC; GV; T-TP, TS-- } \\
\text { TX }\end{array}$ \\
\hline $\begin{array}{l}\text { Social } \\
\text { Sciences }\end{array}$ & $\begin{array}{l}\text { Anthropology, criminology, economics, } \\
\text { history (general), history of the Americas, } \\
\text { history (Africa \& Oceania), history (Asia), } \\
\text { history (Europe), law, library science, political } \\
\text { science, psychology, sociology and social } \\
\text { sciences }\end{array}$ & $\begin{array}{l}\text { GN, GR, GT; HV; HB, } \\
\text { HC, HD; C; E, F; DT, DU; } \\
\text { DS; D (except for DS, DT, } \\
\text { DU); K; Z; HX, J; BF; H, } \\
\text { HA, HM-HT }\end{array}$ \\
\hline
\end{tabular}

\begin{tabular}{|c|c|c|c|c|c|}
\hline \multicolumn{6}{|c|}{$\begin{array}{c}\text { TABLE } 4 \\
\text { E-book Collections Included in Study }\end{array}$} \\
\hline Publisher & Acquired & Package Type & $\begin{array}{c}\text { Titles } \\
\text { Available }\end{array}$ & $\begin{array}{c}\text { Titles Used } \\
\text { Jul13- } \\
\text { Nov14 }\end{array}$ & $\begin{array}{l}\text { \% Use } \\
\text { Jul13- } \\
\text { Nov14 }\end{array}$ \\
\hline Cambridge & 2013-14 & $\begin{array}{l}\text { Consortially purchased } \\
\text { DDA }\end{array}$ & 158 & 50 & $32 \%$ \\
\hline Ebrary & $\begin{array}{l}2006- \\
2014\end{array}$ & $\begin{array}{l}\text { Locally subscribed } \\
\text { aggregator package } \\
\text { with several hundred } \\
\text { consortially purchased } \\
\text { DDA titles }\end{array}$ & 25,648 & 2,517 & $10 \%$ \\
\hline Oxford & $\begin{array}{l}2008- \\
2014\end{array}$ & $\begin{array}{l}\text { Consortially purchased } \\
\text { publisher package }\end{array}$ & 10,501 & 880 & $8 \%$ \\
\hline Springer* & $\begin{array}{l}2008- \\
2014\end{array}$ & $\begin{array}{l}\text { Consortially purchased } \\
\text { publisher package }\end{array}$ & 34,450 & 4,854 & $14 \%$ \\
\hline Wiley & $\begin{array}{l}2012- \\
2014\end{array}$ & $\begin{array}{l}\text { Consortially purchased } \\
\text { publisher package }\end{array}$ & 2,391 & 422 & $18 \%$ \\
\hline Total & & & 73,148 & 8,723 & $12 \%$ \\
\hline
\end{tabular}


data were available (see table 4). The only package that fit these criteria but could not be included was Safari, an e-book package of technical books, because title lists and adequate usage reports were unavailable.

The number and subject distribution of titles owned was determined by downloading title lists from the publishers' websites and using either the call number or subject area assigned to each title on that list. The lists were downloaded between November 2014 and June 2015. To determine the number and subject distribution of titles used, the author downloaded COUNTER BR2 usage reports for July 2013-November 2014 from the publishers' websites and downloaded call numbers for each book from GOBI (EBSCO's - formerly YBP's - book acquisition software) by matching on ISBN. (COUNTER BR2 reports list each title that has gotten a full-text download and how many downloads were made from that title in a given time period.) Most, but not all, titles could be matched to a call number. E-books were broken out into the same subject and discipline groups as the print titles. For two packages, Oxford and Springer, usage reports were also downloaded from the OhioLINK Electronic Book Center (a separate platform that provides access to many of the books purchased by OhioLINK), combined with those publishers' BR2 reports, and deduplicated to get an accurate picture of all titles used in those packages.

Looking at the number of titles used in each format allowed for a comparison of the level of use of print to electronic nonreference monographs that bypassed the shortcomings of comparing the number of accesses or downloads of e-books to the number of circulations of print to assess which group of titles received more use.

\section{Findings}

\section{Print Book Use}

The oldest group of print books included in the study (those that were purchased in 2008-2009 and therefore had been part of the collection for six years) had a use rate of 74 percent by 2014, where 74 percent of the titles had at least one circulation or in-house use since their date of purchase-much greater than the 60 percent overall use rate often cited. This use rate also compares favorably to those in other published use studies.

\begin{tabular}{|c|c|c|c|}
\hline \multicolumn{4}{|c|}{ TABLE 5 } \\
Use of Print Monographs Acquired \\
2008-2013 \\
\hline $\begin{array}{c}\text { Year } \\
\text { Purchased }\end{array}$ & $\begin{array}{c}\text { Titles } \\
\text { Purchased }\end{array}$ & $\begin{array}{c}\text { Titles With } \\
\text { 0 Use }\end{array}$ & $\begin{array}{c}\text { \% } \\
\text { Use }\end{array}$ \\
\hline $2008-2009$ & 8,477 & 2,230 & $74 \%$ \\
\hline $2009-2010$ & 7,145 & 2,301 & $68 \%$ \\
\hline $2010-2011$ & 7,671 & 2,596 & $66 \%$ \\
\hline $2011-2012$ & 7,185 & 2,771 & $61 \%$ \\
\hline $2012-2013$ & 6,097 & 3,106 & $49 \%$ \\
\hline
\end{tabular}

\section{Print Use by Length of Time in Collection}

Table 6 shows how use for monographs purchased from 2008-2009 through 2012-2013 at BGSU grew the longer each group of titles remained in the collection. Even though it is impossible to know when each of BGSU's titles circulated for the first time, we do know both how many titles in each group have ever circulated as well as how many circulated in the "last year/year-to-date" period (July 2013 through November 2014), and these numbers show how use of each group grew the longer the books were owned. The data suggests that, at BGSU, a collection's use will continue to grow throughout the first six years its titles are available, though the rate of growth will be greatest in the first three years.

The authors of the Pittsburgh study concluded that if a book hadn't been used in its first two years in the collection it was unlikely to be used at all, but studies other than this one suggest that the period of growth lasts longer than that. ${ }^{15}$ Cornell found 


\begin{tabular}{|c|c|c|c|c|c|c|c|c|c|}
\hline \multicolumn{10}{|c|}{$\begin{array}{c}\text { TABLE } 6 \\
\text { Growth in Use of Bowling Green State University Print Monographs by Time } \\
\text { Owned }\end{array}$} \\
\hline $\begin{array}{c}\text { Year } \\
\text { Purchased }\end{array}$ & $\begin{array}{c}\text { Titles } \\
\text { Purchased }\end{array}$ & $\begin{array}{c}\text { Number } \\
\text { Circulated } \\
\text { LY/YTD } \\
\text { (Jul 2013- } \\
\text { Nov 2014) }\end{array}$ & $\begin{array}{c}\% \\
\text { Circulated } \\
\text { LY/YTD }\end{array}$ & $\begin{array}{c}\text { Years in } \\
\text { Collection }\end{array}$ & $\begin{array}{c}\text { Number } \\
\text { Circulated } \\
\text { before } \\
2013\end{array}$ & $\begin{array}{c}\% \\
\begin{array}{c}\text { Circulated } \\
\text { before } \\
2013\end{array}\end{array}$ & $\begin{array}{c}\text { Years in } \\
\text { Collection }\end{array}$ & $\begin{array}{c}\text { Total \# } \\
\text { Circulated }\end{array}$ & $\begin{array}{l}\text { Total \% } \\
\text { Circulated } \\
\text { as of Nov. } \\
\quad 2014\end{array}$ \\
\hline $\begin{array}{l}2013- \\
14\end{array}$ & 2,767 & 848 & $31 \%$ & 1 & 0 & $0 \%$ & $\begin{array}{c}0 \\
\text { years }\end{array}$ & 848 & $31 \%$ \\
\hline $\begin{array}{l}2012- \\
13\end{array}$ & 6,097 & 1,956 & $32 \%$ & 2 & 805 & $13 \%$ & year 1 & 2,761 & $45 \%$ \\
\hline $\begin{array}{l}2011- \\
12\end{array}$ & 7,185 & 2,132 & $30 \%$ & 3 & 1,988 & $28 \%$ & $\begin{array}{c}\text { year } \\
1-2\end{array}$ & 4,120 & $57 \%$ \\
\hline $\begin{array}{l}2010- \\
11\end{array}$ & 7,671 & 2,085 & $27 \%$ & 4 & 2,662 & $35 \%$ & $\begin{array}{c}\text { year } \\
1-3\end{array}$ & 4,747 & $62 \%$ \\
\hline $\begin{array}{l}2009- \\
10\end{array}$ & 7,145 & 1,605 & $22 \%$ & 5 & 2,930 & $41 \%$ & $\begin{array}{c}\text { year } \\
1-4\end{array}$ & 4,535 & $63 \%$ \\
\hline $\begin{array}{l}2008- \\
09\end{array}$ & 8,477 & 1,719 & $20 \%$ & 6 & 4,146 & $49 \%$ & $\begin{array}{c}\text { year } \\
1-5\end{array}$ & 5,865 & $69 \%$ \\
\hline
\end{tabular}

the "interval of active discovery" to be 12 years, not two. ${ }^{16}$ At Lingnan University it was seven years. ${ }^{17}$ De Jager did not specify when use at the University of Cape Town plateaued but did say that more than three years of ownership was necessary for a group of books to reach maximum use..$^{18}$ Burrell also addressed this topic: in attempting to develop a mathematical model to predict how much of a collection will account for 80 percent of circulations, he showed that time influences circulation and concluded that, "When we observe a fixed collection over an increasing length of time we find that gradually more and more of the items are circulated for the first time so that gradually the size of the circulating collection increases." ${ }^{19}$ Though, like de Jager, he did not provide a time period to plateau, his model was derived by looking at the use of four collections over a four-year window; percent use in all grew during that period.

\section{Print Use by Subject and Discipline}

Overall use for each subject and discipline was determined by looking at use of all years' purchases in the aggregate. As shown in tables 7 and 8, the discipline with the

\begin{tabular}{|l|c|c|c|}
\hline \multicolumn{4}{|c|}{ TABLE 7 } \\
\hline \multicolumn{1}{|c|}{ Print Use by Discipline, All Years } \\
\hline Discipline & Total Purchases & Titles With 0 Use & \% Use \\
\hline Business & 3,288 & 995 & $70 \%$ \\
\hline Humanities & 1,432 & 455 & $68 \%$ \\
\hline Sciences & 11,022 & 3,862 & $65 \%$ \\
\hline Social Sciences & 7,226 & 2,705 & $63 \%$ \\
\hline General & 13,582 & 4,982 & $63 \%$ \\
\hline Total & 25 & 5 & $80 \%$ \\
\hline
\end{tabular}




\begin{tabular}{|l|c|c|c|c|c|}
\hline \multicolumn{7}{|c|}{ TABLE 8 } \\
\hline \multicolumn{1}{|c|}{ Print Use by Discipline, Individual Years } \\
\hline Business & $\mathbf{2 0 0 8 - 2 0 0 9}$ & $\mathbf{2 0 0 9 - 2 0 1 0}$ & $\mathbf{2 0 1 0 - 2 0 1 1}$ & $\mathbf{2 0 1 1 - 2 0 1 2}$ & $\mathbf{2 0 1 2 - 2 0 1 3}$ \\
\hline Education & $74 \%$ & $72 \%$ & $73 \%$ & $54 \%$ & $46 \%$ \\
\hline Humanities & $77 \%$ & $69 \%$ & $71 \%$ & $71 \%$ & $57 \%$ \\
\hline General & $74 \%$ & $69 \%$ & $67 \%$ & $64 \%$ & $50 \%$ \\
\hline Sciences & $83 \%$ & $83 \%$ & $100 \%$ & $67 \%$ & $100 \%$ \\
\hline Social Sciences & $72 \%$ & $66 \%$ & $65 \%$ & $58 \%$ & $48 \%$ \\
\hline
\end{tabular}

highest percent use overall was education, but use in all disciplines across all years was very strong.

When use by subject was examined in the aggregate, eleven subject areas showed that 70 percent or more of purchases made from 2008-2009 to 2012-2013 had been used at least once (though some of these had relatively few purchases), while only four subjects had a use rate of less than 50 percent (see tables $9 \mathrm{a}$ and $9 \mathrm{~b}$ ).

Other studies have concluded that areas of collection strength tend to circulate at higher rates than areas that are less carefully built or have fewer titles. ${ }^{20}$ However, the subjects with the highest rate of use at Bowling Green State University were not necessarily those that saw the highest rate of purchasing, though two were: education and sociology and social sciences ranked one and three respectively in number of purchases made. It is unclear exactly what other factors spurred the high rate of use of BGSU's most popular subjects.

The lowest-used subjects were mostly in the sciences and non-English languages. This is consistent with existing studies. In the United States, circulation at academic libraries of non-English language books and "ethnocentric" subject areas, such as physics and mathematics, tends to be lower because the audience for these books is smaller than for English-language books and interdisciplinary subjects. ${ }^{21} \mathrm{~A}$ total of 61

\begin{tabular}{|l|c|c|c|}
\hline \multicolumn{4}{|c|}{ TABLE 9A \& 9B } \\
\hline \multicolumn{3}{|c|}{ Highest and Lowest-Use Subjects } \\
\hline \multicolumn{1}{|c|}{ Highest-Use Subjects (All Subjects with a Rate of Use of 70\% or Greater) } \\
\hline & $\begin{array}{c}\text { Titles } \\
\text { Purchased }\end{array}$ & $\begin{array}{c}\text { Titles } \\
\text { With 0 Use }\end{array}$ & $\%$ \\
\hline Library Science & 138 & 23 & $83 \%$ \\
\hline General Works & 25 & 5 & $80 \%$ \\
\hline Photography & 268 & 55 & $79 \%$ \\
\hline Recreation \& Leisure & 815 & 188 & $77 \%$ \\
\hline Languages \& Literatures, Asian & 60 & 15 & $75 \%$ \\
\hline Medicine & 1,193 & 312 & $74 \%$ \\
\hline Languages \& Linguistics & 897 & 249 & $72 \%$ \\
\hline Film & 1,232 & 361 & $71 \%$ \\
\hline Sociology and Social Sciences & 2,514 & 747 & $70 \%$ \\
\hline Psychology & 703 & 209 & $70 \%$ \\
\hline Education & 3,288 & 995 & $70 \%$ \\
\hline
\end{tabular}




\begin{tabular}{|l|c|c|c|}
\hline \multicolumn{4}{|c|}{ TABLE 9A \& 9B } \\
Highest and Lowest-Use Subjects \\
\hline Subject & $\begin{array}{c}\text { Titles } \\
\text { Purchased }\end{array}$ & $\begin{array}{c}\text { Titles With } \\
\text { 0 Use }\end{array}$ & $\%$ Use \\
\hline Literature, Germanic & 184 & 105 & $43 \%$ \\
\hline Geology & 99 & 55 & $44 \%$ \\
\hline Languages \& Literatures, Romance & 527 & 272 & $48 \%$ \\
\hline Physics \& Astronomy & 471 & 240 & $49 \%$ \\
\hline History & 93 & 43 & $54 \%$ \\
\hline Political Science & 2,658 & 1,226 & $54 \%$ \\
\hline Mathematics & 1,067 & 467 & $56 \%$ \\
\hline Literature, English \& American & 2,110 & 899 & $57 \%$ \\
\hline Biological Sciences \& General Science & 1,335 & 568 & $57 \%$ \\
\hline Law & 460 & 191 & $58 \%$ \\
\hline Technology & 999 & 414 & $59 \%$ \\
\hline Chemistry & 110 & 45 & $59 \%$ \\
\hline
\end{tabular}

percent of Cornell's English-language books published between 1990 and 2010 had circulated by 2010, while the highest percent-use of a language other than English was 34 percent. ${ }^{22}$ In the OhioLINK consortium, Spanish-language books circulated half as much as English in 2007, and all other languages were used even less. ${ }^{23}$ Kent et al also noted the comparatively low circulation of non-English language books. ${ }^{24}$

\section{Print Use by Order Method}

Firm order books were, overall, used slightly more than approval books, but the difference between the two methods of acquisition was not great.

\begin{tabular}{|c|c|c|c|c|c|}
\hline \multicolumn{6}{|c|}{$\begin{array}{c}\text { TABLE } 10 \\
\text { Print Use by Order Method }\end{array}$} \\
\hline \multicolumn{6}{|c|}{ By Year } \\
\hline Order Method & 2008-2009 & 2009-2010 & 2010-2011 & 2011-2012 & 2012-2013 \\
\hline$\%$ use firm order & $75 \%$ & $71 \%$ & $69 \%$ & $62 \%$ & $51 \%$ \\
\hline$\%$ use approval & $73 \%$ & $67 \%$ & $65 \%$ & $61 \%$ & $49 \%$ \\
\hline \multicolumn{6}{|c|}{ By Discipline } \\
\hline \multicolumn{4}{|c|}{ Discipline } & $\begin{array}{l}\text { \% Use } \\
\text { Firm }\end{array}$ & $\begin{array}{c}\text { \% Use } \\
\text { Approval }\end{array}$ \\
\hline \multicolumn{4}{|l|}{ Business } & $66 \%$ & $69 \%$ \\
\hline \multicolumn{4}{|l|}{ Education } & $75 \%$ & $68 \%$ \\
\hline \multicolumn{4}{|c|}{ General (only 25 titles) } & $67 \%$ & $84 \%$ \\
\hline \multicolumn{4}{|c|}{ Humanities } & $68 \%$ & $64 \%$ \\
\hline \multicolumn{4}{|l|}{ Sciences } & $63 \%$ & $62 \%$ \\
\hline \multicolumn{4}{|l|}{ Social Sciences } & $67 \%$ & $62 \%$ \\
\hline
\end{tabular}


This supports Tyler's findings at the University of Nebraska: approval books did not circulate as well as librarian selections there. ${ }^{25}$ However, Kingsley drew the opposite conclusion: of about 1,000 books cataloged at Western Michigan in September 1995, 50 percent of approval books had circulated within 5 months, while only 29 percent of books acquired by other means had circulated in the same period. ${ }^{26}$ Whether or not books acquired via an approval plan reach the same level of use as librarian purchases depends in part on how individual libraries structure both methods of acquisition; however, the author was surprised at the low variance between these methods at Bowling Green State University over this time period.

\section{E-book Use}

Though Bowling Green State University offers five undergraduate and 18 graduate degrees that are fully online, as well as additional blended degree programs and numerous online courses, e-book use at Bowling Green State University lags behind print book use. Even though the library acquired more than twice as many e-books as print books between 2008 and 2014, more print titles circulated between July 2013 and November 2014 than e-book titles were used during that time. In addition, a higher percentage of titles were used in print than were used electronically. While 27 percent of the print books acquired between 2008 and 2014 circulated at least once between July 2013 and November 2014, only 12 percent of e-book titles had at least one use (see table 11). In addition, use of recently purchased monographs in every discipline was lower for e-books than for print-in some disciplines much lower.

\begin{tabular}{|c|c|c|c|c|c|c|}
\hline \multicolumn{7}{|c|}{$\begin{array}{c}\text { TABLE 11 } \\
\text { Percent Use of Ebooks and Print Books Between } \\
\text { July } 2013 \text { and November } 2014\end{array}$} \\
\hline \multirow[t]{2}{*}{ Discipline } & \multicolumn{3}{|c|}{ E-books } & \multicolumn{3}{|c|}{ Print Books } \\
\hline & $\begin{array}{c}\text { Acquired } \\
\text { 2008-2014 }\end{array}$ & $\begin{array}{l}\text { Used Jul13- } \\
\text { Nov14 }\end{array}$ & $\begin{array}{l}\% \\
\text { Use }\end{array}$ & $\begin{array}{c}\text { Acquired } \\
2008-2014\end{array}$ & $\begin{array}{c}\text { Circulated } \\
\text { Jul13-Nov14 }\end{array}$ & $\begin{array}{l}\% \\
\text { Use }\end{array}$ \\
\hline Business & 8,021 & 760 & $9 \%$ & 1,499 & 331 & $22 \%$ \\
\hline Education & 4,970 & 884 & $18 \%$ & 3,502 & 1,124 & $32 \%$ \\
\hline General & 53 & 10 & $19 \%$ & 28 & 22 & $79 \%$ \\
\hline Humanities & 6,330 & 1,541 & $24 \%$ & 11,915 & 3,202 & $27 \%$ \\
\hline Sciences & 33,100 & 3,409 & $10 \%$ & 7,858 & 2,040 & $26 \%$ \\
\hline $\begin{array}{l}\text { Social } \\
\text { Sciences }\end{array}$ & 20,439 & 1,866 & $9 \%$ & 14,540 & 3,756 & $26 \%$ \\
\hline Unmatched & 235 & 253 & & & & \\
\hline Total & 73,148 & 8,723 & $12 \%$ & 39,342 & 10,475 & $27 \%$ \\
\hline
\end{tabular}

\section{Collection Patterns and Use}

Collection patterns at Bowling Green State University for e-books and print books were very different between 2008 and 2014. Of the print books purchased between 2008 and 2014, 70 percent were in the social sciences and humanities. Fully 7 out of $10(70 \%)$ of the purchases that were used in that same period were also in the social sciences and humanities, as were 70 percent of the titles that circulated between July 2013 and November 2014. 


\begin{tabular}{|l|c|c|c|c|c|c|}
\hline \multicolumn{7}{|c|}{ TABLE 12 } \\
\hline Discipline & $\begin{array}{c}\text { Titles } \\
\text { Purchased } \\
\text { 2008-2014, } \\
\text { by Discipline }\end{array}$ & $\begin{array}{c}\text { \% of Titles } \\
\text { Purchased } \\
\text { in Each } \\
\text { Discipline }\end{array}$ & $\begin{array}{c}\text { Titles } \\
\text { Circ'd by } \\
\text { Discipline }\end{array}$ & $\begin{array}{c}\text { \% Circ'd } \\
\text { 2008-2014 } \\
\text { of All Titles } \\
\text { Purchased }\end{array}$ & $\begin{array}{c}\text { \# Titles } \\
\text { Circ'd } \\
\text { Jul13- } \\
\text { Nov14 }\end{array}$ & $\begin{array}{c}\text { \% of } \\
\text { All } \\
\text { Circ'd }\end{array}$ \\
\hline Business & 1,499 & $4 \%$ & 1,002 & $4 \%$ & 364 & $3 \%$ \\
\hline Education & 3,502 & $9 \%$ & 2,377 & $10 \%$ & 814 & $8 \%$ \\
\hline Humanities & 11,915 & $30 \%$ & 7,481 & $31 \%$ & 3,522 & $34 \%$ \\
\hline Sciences & 7,651 & $20 \%$ & 4,728 & $19 \%$ & 1,978 & $19 \%$ \\
\hline $\begin{array}{l}\text { Social } \\
\text { Sciences }\end{array}$ & 14,540 & $37 \%$ & 8,916 & $36 \%$ & 3,757 & $36 \%$ \\
\hline Total* & 39,107 & & & & 10,435 & \\
\hline
\end{tabular}

By contrast, only 37 percent of e-books collected during the same period were in the social sciences and humanities. Again, usage rates by discipline for e-books aligned with collection rates (see table 13).

BGSU's data suggest that monograph use patterns follow collection patterns for both print books and $\mathrm{e}=$ books, and data from other $\mathrm{e}=$ book studies confirm this.

In two short pilots carried out at the California State University System in 2011 and 2012, Shepherd and Langston found the number of books purchased in each subject to be largely proportional to the number of records available in that subject. ${ }^{27}$

McLure and Hoseth's data also show that use generally followed availability in Colorado State University's DDA program in 2010, though it did not correlate as closely as it did at BGSU (see table 14). ${ }^{28}$

Levine-Clark looked at use of all 642,885 e-brary titles available worldwide in 2014 and shared the percentages of titles available and used in each of three disciplines that year. Again, the numbers are proportional (see table 15). ${ }^{29}$

Does this mean that, if libraries collected more e-books in the humanities and social sciences, e-book use patterns would not lean as heavily toward STEM disciplines and would instead mirror the use patterns of print books? The author believes yes - but at a cost: libraries could also see lower overall monograph use than we do with print

\begin{tabular}{|l|c|c|c|c|}
\hline \multicolumn{5}{|c|}{ TABLE 13 } \\
\hline & $\begin{array}{c}\text { Titles Purchased } \\
\text { 2008-2014, by } \\
\text { Discipline }\end{array}$ & $\begin{array}{c}\text { \% of Titles } \\
\text { Purchased in } \\
\text { Each Discipline }\end{array}$ & $\begin{array}{c}\text { \# Titles Used } \\
\text { Jul13-Nov14 }\end{array}$ & $\begin{array}{c}\text { \% of All } \\
\text { Used }\end{array}$ \\
\hline Business & 8,121 & $11 \%$ & 760 & $9 \%$ \\
\hline Education & 4,970 & $7 \%$ & 884 & $10 \%$ \\
\hline General & 53 & $0 \%$ & 10 & $0 \%$ \\
\hline Humanities & 6,330 & $9 \%$ & 867 & $10 \%$ \\
\hline Sciences & 33,100 & $45 \%$ & 4,083 & $47 \%$ \\
\hline Social Sciences & 20,439 & $28 \%$ & 1,866 & $21 \%$ \\
\hline Unmatched & 235 & & 253 & \\
\hline Total & 73,248 & & 8,723 & \\
\hline
\end{tabular}




\begin{tabular}{|l|c|c|c|c|}
\hline \multicolumn{5}{|c|}{ TABLE 14 } \\
\hline & $\begin{array}{c}\text { Titles } \\
\text { Available }\end{array}$ & $\begin{array}{c}\text { \%o of Titles in } \\
\text { Discipline As \% } \\
\text { of All Available } \\
\mathbf{( 7 , 9 4 2 )}\end{array}$ & $\begin{array}{c}\text { \# Titles } \\
\text { Used }\end{array}$ & $\begin{array}{c}\text { \% of Titles Used } \\
\text { in Discipline As } \\
\text { \% of All Used } \\
\mathbf{( 9 2 3 )}\end{array}$ \\
\hline Business & 1,432 & $18 \%$ & 132 & $14 \%$ \\
\hline Education & 505 & $6 \%$ & 56 & $6 \%$ \\
\hline Humanities & 1,129 & $14 \%$ & 84 & $9 \%$ \\
\hline Sciences & 2,758 & $35 \%$ & 446 & $48 \%$ \\
\hline Social Sciences & 2,110 & $27 \%$ & 204 & $22 \%$ \\
\hline Uncategorized & 8 & $0 \%$ & 1 & $0 \%$ \\
\hline Total & 7,942 & & 923 & \\
\hline
\end{tabular}

collections. Knowlton examined access and use of print and e-books to calculate user preference for e-books by subject. He concluded that, at his institution, "preference does seem to have more influence than availability in dictating format choice," meaning that simple availability of books in electronic format is not the only, or most important, factor driving use. ${ }^{29}$ Even when use patterns follow collection patterns, format preference may still play a significant role. And, while users are increasingly willing to use e-books, surveys indicate they still, overall, prefer print: the author examined ten user surveys published between 2011 and 2016, and all showed that the largest number of respondents indicated a preference for print. ${ }^{30}$

BGSU'S recently acquired print books might have been more in demand than our e-books not only because of format preference and discipline distribution, but also because the print titles were more relevant to our users' needs. For example, many of the e-books available to Bowling Green State University users are in medicine and engineering, but Bowling Green State University does not have medical or engineering degree programs.

Acquiring e-books locally, especially via DDA, could definitely boost the relevance of BGSU'S e-book collections. However, despite the fact that BGSU's e-books were consortial purchases of publisher packages, their overall rate of use during the year studied is comparable to what many libraries have experienced with DDA plans (see table 2). In fact, only two usage studies involving e-book collections of any kind larger than 2,000 titles have shown use of a significant portion of the titles. Dewland and See were enthusiastic about the University of Arizona's "significant decrease in the acquisitions budget" after implementing a DDA program, but they ignored the fact

\begin{tabular}{|l|c|c|}
\hline \multicolumn{3}{|c|}{ TABLE 15 } \\
Worldwide Ebrary Usage By Discipline, 2014 \\
\hline \multicolumn{1}{|c|}{ Discipline } & $\begin{array}{c}\text { Ebrary Available in } \\
\mathbf{2 0 1 4} \text { (642,885 Titles) }\end{array}$ & $\begin{array}{c}\text { Ebrary Used (Just over } \\
\mathbf{5 3 \%} \text { of Available) }\end{array}$ \\
\hline Humanities & $28.9 \%$ & $32 \%$ \\
\hline Sciences & $30.2 \%$ & $29 \%$ \\
\hline $\begin{array}{l}\text { Social Sciences (including Business } \\
\text { and Education) }\end{array}$ & $28.6 \%$ & $34 \%$ \\
\hline
\end{tabular}


that this was largely because their users were choosing to use very few e-books at all: even few enough to force a purchase of one via DDA. ${ }^{32}$

It remains to be seen if the use rate of e-book collections will ever approach the use rate of print collections, and the data available make this far from certain. As Knowlton wrote, "if librarians blithely steer patrons toward e-books even in those fields where patrons have demonstrated a collective preference for print books, they may be unwittingly deterring use by making a majority of new titles available only in formats their patrons are disinclined to read." ${ }^{33}$ The lower overall rate of use of e-books in most studies seems to bolster this conclusion.

\section{Falling Circulation: Are Print Books Less Valued?}

At Bowling Green State University (as at many universities), overall circulation is declining (see figure 1).

\begin{tabular}{|c|c|c|c|c|c|}
\hline & & Cir & $\begin{array}{l}\text { FIGUR } \\
\text { n at BGS }\end{array}$ & 0-2014 & \\
\hline & 120,000 & & & & \\
\hline 등 & 100,000 & 96,123 & 95,443 & & \\
\hline 䒕 & 80.000 & 32126 & 30.421 & 01,215 & 76,245 \\
\hline.$\overline{0}$ & 60,000 & & & 28,895 & 27,514 \\
\hline $\bar{\sigma}$ & 40,000 & & C5 $00 ?$ & & \\
\hline 음 & 20,000 & 03,991 & $05, U<2$ & 58,320 & 48,731 \\
\hline & & 2010-11 & 2011-12 & $2012-13$ & 2013-14 \\
\hline & & & & & \\
\hline & & Total & sk Check & otal Rene & \\
\hline
\end{tabular}

Does this mean print books are less valuable to our users and the library should acquire fewer of them? The strong rate of use of new purchases suggests there are other reasons for this. One might be BGSU'S falling rate of print book acquisition: Bowden found that collection size contributed significantly to collection use. ${ }^{34}$ Lower enrollment could be another: at the University of Nevada Las Vegas between 2002 and 2007, collection use patterns followed enrollment patterns. ${ }^{35}$ Also, Bowling Green State University had nearly 200 fewer full-time faculty members in 2013-2014 than it did in 2008-2009, and both Cornell and Virginia Tech found that faculty were responsible for the circulation of more books than undergraduates, despite the difference in the size of these user populations. ${ }^{36}$

The implementation of a discovery layer (Summon) in summer 2011 has probably also played a role in BGSU'S falling circulation. Before the 2011-2012 academic year, the default search box on the library's home page searched the catalog, and thus users were directed primarily to books for the majority of their information needs. Beginning in 2011-2012, the default search box changed to search Summon, and users now find full-text articles alongside books and can choose which will better fill their need.

\section{Conclusions and Suggestions for Further Research}

Academic librarians have embraced e-books and DDA purchasing models with great enthusiasm while being critical of the number of unused books collected through traditional print collection development models. ${ }^{37}$ At BGSU, data show that recently 
purchased print books are enjoying a high level of use, comparing favorably both to the levels of use presented in other published print use studies and the level of use commonly cited for academic library collections, despite the fact that overall print circulation is falling. BGSU's data also show that e-books purchased at the same time had a lower rate of use in one recent year than these print purchases.

Despite the fact that the e-books available to Bowling Green State University users were mainly consortial purchases of front-list publisher packages, their rate of use was comparable to the overall rate of use of e-books made available via DDA plans at a number of other libraries in the past several years. Though most DDA studies have celebrated the success of their programs, the data from this and other use studies of ebooks suggest that migrating monograph collections from print to online could have a detrimental impact on the overall use of monographs in an academic library collection.

Published studies of DDA use indicate that libraries can expect a very small percent of available records to receive any use when they are first added to the collection. Because it can take print books up to 12 years to see their first circulation, the period of discovery for e-books may be similar. However, because users still largely prefer print books, the unavailability of desired books in print format could also affect the overall rate of use of any e-book collection. Assessing the period to maximum use for groups of e-books by acquisition model (publisher package, aggregator package, and DDA) and assessing which acquisition models result in the highest rates of use for available titles and how these ultimately compare to different models of print acquisition are potential areas for further research for libraries. A complicating factor in discovering this information will be the difficulty in knowing exactly which e-books are made available when in different models.

As the balance of print and electronic monographs in academic library collections continues to evolve, libraries should pay attention to the availability of desirable titles in e-book format while acknowledging user preferences to reach their long-term collection goals, including goals for monograph use.

\section{Acknowledgements}

The author thanks Jennifer Harvey for her support of, feedback on, and participation in this research.

\section{Notes}

1. Allen Kent et al., Use of Library Materials: The University of Pittsburgh Study (New York: Marcel Dekker, 1979).

2. Sources: a) Charles A. Hamaker, "Management Data for Selection Decisions in Building Library Collections," Journal of Library Administration 17, no. 2 (1992): 71-97, doi:10.1300/ J111v17n02_07; b) John S. Davidson, "The Use of Books in a College Library," College \& Research Libraries (Sept. 1943): 294-97; c) Kingsley, "Circulation Statistics"; d) Robert Alan, Tina E. Chrzastowski, Lisa German, and Lynn Wiley, "Approval Plan Profile Assessment in Two Large ARL Libraries University of Illinois at Urbana-Champaign and Pennsylvania State University," Library Resources \& Technical Services 54, no. 2 (2010): 64-76; e) Alan, Chrzastowski, German, and Wiley, "Approval Plan Profile Assessment"; f) Kay Downey, Yin Zhang, Cristobal Urbano, and Tom Klinger, "A Comparative Study of Print Book and DDA Ebook Acquisition and Use," Technical Services Quarterly 31, no. 2 (2014): 139-60, doi:10.1080/07317131.2014.875379; g) Wiley, Chrzastowski, and Baker, "A Domestic Monograph Collection Assessment"; h) Ruth E. Fenske, "Evaluation of Monograph Selection in a Health Sciences Library," Bulletin of the Medical Library Association 82, no. 3 (1994): 265-70; i) Deborah D. Blecic, Joan B. Fiscella, and Stephen E. Wiberley Jr., "Measurement of Use of Electronic Resources: Advances in Use Statistics and Innovations in Resource Functionality," College \& Research Libraries 68, no. 1 (2007): 26-44; j) Michael Levine-Clark, "Developing a Multiformat Demand-Driven Acquisition Model," Collection Management 35, no. 3 (2010): 201-07; k) Jonathan D. Eldredge, "The Vital Few Meet the Trivial Many: Unexpected Use Patterns in a Monographs Collection," Bulletin of the Medical Library Association 86, no. 4 (1998): 496-503; 1) Robert Danielson, "A Dual Approach to Assessing Collection Development and Ac- 
quisitions for Academic Libraries," Library Collections Acquisitions \& Technical Services 36, no. 3/4 (2012): 84-96, doi:10.1016/j.lcats.2012.09.002; m) Sheila Cheung, Terry Chung, and Frederick Nesta, "Monograph Circulation over a 15-Year Period in a Liberal Arts University," Library Management 32, no. 6 (2011): 419-34, doi:10.1108/01435121111158565; n) Cornell University Library, Report of the Collection Development Executive Committee Task Force on Print Collection Usage Cornell University Library (Ithaca, N.Y.: Cornell University, 2010), available online at https://ecommons.cornell.edu/ handle/1813/45424 [accessed 11 December 2017].

3. Marc Langston, "The California State University E-Book Pilot Project: Implications for Cooperative Collection Development," Library Collections, Acquisitions, E Technical Services 27, no. 1 (2003): 19-32.

4. Terry Bucknell, "The 'Big Deal' Approach to Acquiring E-Books: A Usage-Based Study," Serials: The Journal for the Serials Community 23, no. 2 (2010): 126-34, doi:10.1629/23126.

5. Lisa Rose-Wiles, "Are Print Books Dead? An Investigation of Book Circulation at a MidSized Academic Library," Technical Services Quarterly 30, no. 2 (2013): 129-52, doi:10.1080/073171 31.2013.759496.

6. Steven A. Knowlton, "A Two-Step Model for Assessing Relative Interest in E-Books Compared to Print," College \& Research Libraries 77, no. 1 (2016): 20-33.

7. Sources: a) Lynn Wiley and Elizabeth Clarage, "Building on Success: Evolving Local and Consortium Purchase-on-Demand Programs," Interlending \& Document Supply 4, no. 2 (2012): 105-10; b) Tina E. Chrzastowski and Lynn N. Wiley, "E-Book Use and Value in the Humanities," Library Resources \& Technical Services 59, no. 4 (2015): 172-86; c) Mark Tynan and Eoin McCarney, "'Click Here to Order this Book': A Case Study of Print and Electronic Patron-Driven Acquisition in University College Dublin," New Review of Academic Librarianship 20, no. 2 (2014): 233-50, do i:10.1080/13614533.2014.906352; d) Merinda McLure and Amy Hoseth, "Patron-Driven e-Book Use and Users' e-Book Perceptions: A Snapshot," Collection Building 31, no. 4 (2012): 136-47; e) Fischer et al., "Give 'Em What They Want"; f) Kay Downey, Yin Zhang, Cristobal Urbano, and Tom Klinger, "A Comparative Study of Print Book and DDA Ebook Acquisition and Use," Technical Services Quarterly 31, no. 2 (2014): 139-60, doi:10.1080/07317131.2014.875379; g) Mary Gilbertson, Elizabeth Chadbourn McKee, and Lutishoor Salisbury, "Just in Case or Just in Time? Outcomes of a 15-Month Patron-Driven Acquisition of E-Books at the University of Arkansas Libraries," Library Collections, Acquisitions, \& Technical Services 38, no. 1 (2014): 10-20, http://www.tandfonline. com/doi/abs/10.1080/14649055.2014.924072; h) Catherine S.Y. Kwok, Diana L.H. Chan, Ada S.M. Cheung, and Ming Kan Wong, "Demand-Driven Acquisition at HKUST Library: The New Normal," Interlending and Document Supply 42, no. 4 (2014): 153-58, doi:10.1108/ILDS-09-2014-0046; Jason C. Dewland and Andrew See, "Patron Driven Acquisitions," Library Resources \& Technical Services 59, no. 1 (2015): 13-23.

8. These articles have compared e-book accesses or downloads to circulations of print books and concluded that e-books are used more: Rusty Kimball, Gary Ives, and Kathy Jackson, "Comparative Usage of Science E-Book and Print Collections at Texas A\&M University Libraries," Collection Management 35, no. 1 (2009): 15-28, doi:10.1080/01462670903386182; Justin Littman and Lynn Silipigni Connaway, "A Circulation Analysis of Print Books and e-Books in an Academic Research Library," Library Resources \& Technical Services 48, no. 4 (2004): 256-62; Karen S. Fischer, Michael Wright, Kathleen Clatanoff, Hope Barton, and Edward Shreeves, "Give 'Em What They Want: A One-Year Study of Unmediated Patron-Driven Acquisition of e-Books," College \& Research Libraries 73, no. 5 (2012): 469-92.

9. Littman and Connaway, "A Circulation Analysis."

10. Marilyn Christianson and Marsha Aucoin, "Electronic or Print Books: Which Are Used?" Library Collections, Acquisitions, \& Technical Services 29, no. 1 (2005): 71-81, doi:10.1016/j. lcats.2005.01.002.

11. Kimball, Ives, and Jackson, "Comparative Usage."

12. Fischer et al., "Give 'Em What They Want."

13. Cathy Goodwin, "The e-Duke Scholarly Collection: E-Book v. Print Use," Collection Building 33, no. 4 (2014): 101-05, doi:10.1108/CB-05-2014-0024.

14. Jamison F. Conley and Lee Ann Nolan, "Call Number Sorting in Excel," Earth and Mineral Sciences Library, Pennsylvania State University (2014), available online at https://scholarsphere.psu. edu/concern/generic_works/qv33rw719 [accessed 11 December 2017].

15. Kent et al., Use of Library Materials, 10.

16. Cornell University Library, Report of the Collection Development Executive Committee Task Force on Print Collection Usage Cornell University Library (Ithaca, N.Y.: Cornell University, 2010): 12, available online at https://ecommons.cornell.edu/handle/1813/45424 [accessed 11 December 2017].

17. Sheila Cheung, Terry Chung, and Frederick Nesta, "Monograph Circulation Over a 15-Year Period in a Liberal Arts University," Library Management 32, no. 6 (2011): 424, doi:10.1108/01435121111158565. 
18. Karin De Jager, "Obsolescence and Stress: A Study of the Use of Books on Open Shelves at a University Library," Journal of Librarianship \& Information Science 26, no. 2 (1994): 75-76.

19. Quentin L. Burrell, “The 80/20 Rule: Library Lore or Statistical Law?" Journal of Documentation 41, no. 1 (1985): 35.

20. This was true at the CARLI libraries; see Lynn Wiley, Tina E. Chrzastowski, and Stephanie Baker, "A Domestic Monograph Collection Assessment in Illinois Academic Libraries: What Are We Buying and How Is It Used?" Interlending \& Document Supply 39, no. 4 (2011): 173. Metz and Litchfield concluded that holdings statistically explain much of the variation in use between subjects; see Paul Metz and Charles A. Litchfield, "Measuring Collections Use at Virginia Tech," College $\mathcal{E}$ Research Libraries 49, no. 6 (1988): 511.

21. Metz discusses ethnocentricity and shows disciplines with high and low endogenous use in Paul Metz, "Revisiting the Landscape of Literatures: Replication and Change in the Use of Subject Collections," College \& Research Libraries 72, no. 4 (2011): 344-59.

22. Cornell University Library, Report, 14.

23. Edward T. O'Neill and Julia A. Gammon, "Consortial Book Circulation Patterns: The OCLC-OhioLINK Study," College \& Research Libraries 75, no. 6 (2014): 799.

24. Kent et al., Use of Library Materials, 44.

25. David C. Tyler et al., "Patron-Driven Acquisition and Circulation at an Academic Library: Interaction Effects and Circulation Performance of Print Books Acquired Via Librarians' Orders, Approval Plans, and Patrons' Interlibrary Loan Requests," Collection Management 38, no. 1 (2013): 3-32, doi:10.1080/01462679.2012.730494.

26. Marcia Stevenson Kingsley, "Circulation Statistics for Measuring Approval Plan Effectiveness," Against the Grain 8, no. 4 (1996): 1, 16-17.

27. Jodi Shepherd and Marc Langston, "Shared Patron Driven Acquisition of E-Books in the California State University Library Consortium," Library Collections, Acquisitions \& Technical Services 37, no. 1/2 (2013): 34-41.

28. McLure and Hoseth, "Patron Driven E-Book Use."

29. Michael Levine-Clark, “E-Book Usage on a Global Scale: Patterns, Trends and Opportunities," Insights: The UKSG Journal 28, no. 2 (2015): 39-48, doi:10.1629/uksg.240.

30. Knowlton, "A Two-Step Model," 29.

31. In all of the following surveys, results indicate that the majority of the respondents prefer print: Alexander J. Carroll, Kelsey Corlett-Rivera, Timothy Hackman, and Jinwang Zou, "E-Book Perceptions and Use in STEM and Non-STEM Disciplines: A Comparative Follow-Up Study," portal: Libraries \& the Academy 16, no. 1 (2016): 131-62; Choy Fatt Cheong and Ng Chay Tuan, "What Users Want and What Users Do in E-Books: Findings of a Study on Use of E-Books from NTU Library," Singapore Journal of Library \& Information Management 40 (2011): 1-32; Tina E. Chrzastowski and Lynn N. Wiley, "E-Book Use and Value in the Humanities," Library Resources $\mathcal{E}$ Technical Services 59, no. 4 (2015): 172-86; Joe C. Clark, "Format Preferences of Performing Arts Students," Journal of Academic Librarianship 39, no. 3 (2013): 297-307, doi:10.1016/j.acalib.2013.02.005; Jae-Young Hwang, Jayhoon Kim, Boram Lee, and Hwan Kim Jeong, "Usage Patterns and Perception toward e-Books: Experiences from Academic Libraries in South Korea," Electronic Library 32, no. 4 (2014): 522-41; Timothy D. Lincoln, "Reading and E-Reading for Academic Work: Patterns and Preferences in Theological Studies and Religion," Theological Librarianship 6, no. 2 (2013): 34-52; Molly Olney-Zide and Laura Eiford, "Confessions of a Late Bloomer: Use and Acceptance of an E-Books Program in an Undergraduate Library," Serials Librarian 68, no. 1/4 (2015): 307-17, doi:1 0.1080/0361526X.2015.1025656; Leila Rod-Welch, Barbara E. Weeg, Jerry V. Caswell, and Thomas L. Kessler, "Relative Preferences for Paper and for Electronic Books: Implications for Reference Services, Library Instruction, and Collection Management," Internet Reference Services Quarterly 18, no. 3/4 (2013): 281-303; Sarah Smyth and Andrew P. Carlin, "Use and Perception of Ebooks in the University of Ulster: A Case Study," New Library World 112, no. 5/6 (2011): 215-21; Edward W. Walton, "Why Undergraduate Students Choose to Use e-Books," Journal of Librarianship \& Information Science 46, no. 4 (2014): 263-70, doi:10.1177/0961000613488124; Julie Waters, Jennifer Roach, Judith Emde, Scott McEathron, and Keith Russell, "A Comparison of E-Book and Print Book Discovery, Preferences, and Usage by Science and Engineering Faculty and Graduate Students at the University of Kansas," Issues in Science \& Technology Librarianship no. 75 (2014), doi:10.5062/ F48G8HN5.

32. Jason C. Dewland and Andrew See, "Patron Driven Acquisitions," Library Resources \& Technical Services 59, no. 1 (2015): 14.

33. Knowlton, "A Two-Step Model," 31.

34. Virginia M. Bowden, "Current Monograph Collections: Patterns of Ownership and Use in Four Academic Health Sciences Libraries" (doctoral diss., University of Texas at Austin, 1994).

35. James Cory Tucker, "Collection Assessment of Monograph Purchases at the University of Nevada, Las Vegas Libraries," Collection Management 34, no. 3 (2009): 157-81. 
Factors Affecting the Use of Print and Electronic Books 85

36. Cornell University Library, Report; Metz, "Revisiting the Landscape of Literatures."

37. Amy Fry, "Conventional Wisdom or Faulty Logic? The Recent literature on Monograph Use and E-book Acquisition," Library Philosophy and Practice, paper 1307: (2015), available online at http://digitalcommons.unl.edu/libphilprac/1307/ [accessed 19 May 2016]. 